\title{
Challenges of the Polish local self-government in the context of the development of the civil society
}

Keywords: local self-government, administrative unit, gmina, social participation, public bodies, political regime

\begin{abstract}
Political changes in Poland in the last two decades of the $20^{\text {th }}$ century enabled the creation of a new political regime. The development of civil society in the $21^{\text {st }}$ century has aroused curiosity concerning the instruments and forms that promote effective participation and deliberation in the field of local self-government and other areas. The perception of political decisions and their legitimization may be reinforced via the appropriate identification and application of some participatory instruments. Some legal institutions have been established and have been developed in order to increase the scope of civil society in local self-government (e.g., elections to the local authorities, referendums, and public consultations). The latest amendment, enacted on the $11^{\text {th }}$ of January 2018, to the Polish local self-government acts is a step towards the reinforcement of public participation at the local level (the civil budget, participating in the debate on the report on the condition of the of local government unit, and the civil legislative initiative).
\end{abstract}

* ORCID ID: https://orcid.org/0000-0003-0903-7726, Assistant Professor, The Chair of Theory and History of Law and Administration Faculty University of Warmia and Mazury in Olsztyn, Poland. 


\section{Introduction}

The term of civil society, where communities are encouraged to strive for autonomy, has become a fundamental element of modern discourse's notion of well governed state. It is not a synonym of rebellion against a state. Instead the purpose of the activities of civil society is self-organization, which reflects the citizen's subjectivity and human dignity. This is particularly significant in the context of the transformation of the post-communist regimes that were characterized by a distinctive dichotomy between a society and a state ${ }^{1}$. The developing interest in civil society by the representatives of varied scientific areas correlates with the experience of European democratic oppositions and the fall of communism. Different understanding of civil society results from different perceptions of the relationship between an individual and the society, and the role of a state and its connections with varied social groups that act publicly. It should be taken into closer consideration that civil society assumes the active participation of citizens in public life directly or via some established institutions in order to promote and manifest own interests and values, which are independent of the state institutions. Civil society provides society with some autonomous social institutions, which are not controlled centrally by the state authorities ${ }^{2}$. Therefore, it can be assumed that self-government is an expression of civil society, and an indication of the decentralization of modern public administration. It might be also perceived as the local form of organization of state structure that serves the realization of public interest, which goes beyond the local interest.

Political changes in Poland in the last two decades of the $20^{\text {th }}$ century enabled the creation of a new political regime. The resultant changes led to the development of civil society in the $21^{\text {st }}$ century, and these have stimulated some questions concerning the instruments and forms of the effective participation and deliberation in the field of local selfgovernment and other areas. Interest in this subject can be demonstrated by the broad scope of the Polish subject related literature ${ }^{3}$. The purpose

1 A. Arato, The Rise, Decline and Reconstruction of the Concept of Civil Society, and Directions for Future Research, [in:] A. Bibic, G. Graziano (eds.), Civil Society, Political Society, Democracy, Slovenian Political Association, Lubljana 1994, p. 10.

2 For more about the idea of civil society, see M. Kazimierczuk, Wolność zrzeszania sie jako element spoteczeństwa obywatelskiego, «Studia Prawnoustrojowe» 2015, vol. 28, pp. 22-24.

3 See, e.g., T.G. Grosse, Dialog społeczny i obywatelski w Unii Europejskiej, [in:] R. Towalski (ed.), Dialog społeczny. Najnowsze dyskusje i koncepcje, Centrum Partnerstwa Społecznego DIALOG, Fundacja Instytut Spraw Publicznych, Warszawa 2007, pp. 53-74; G. Makowski, Przeglad 
of the article is to present the Polish experience concerning the improvement of self-government at the local level in the context of the development of civil society. The main questions the present study strives to answer are: How has local self-government in Poland changed in the context of the political changes due to the fall of communism, and what forms of the effective participation has it created? How has the Amendment of the $11^{\text {th }}$ of January 2018 to the Polish local self-government Acts fostered civil society through encouraging local level public participation in Poland?

Due to the fact that the article is directed towards an international readership, at first I will present the historical development of Polish local self-government. Then, some new legal instruments that were recently implemented into the Polish political system will be identified. The hypothesis that I adopt is that the Polish legislator has successively made attempts to establish some legal institutions, which have improved Polish civil society in the area of local self-government. In this particular study the, historic-descriptive method of theoretical analysis, and legal methods (including formal legal method) were applied to address the research questions and to then reach some conclusions. Unfortunately, the modest scope of the article does not allow for an exhaustive treatment of the subject, therefore only some issues could be examined in depth.

\section{The evolution of Polish local self-government}

When Poland regained its independence in 1918, within its newly established boarders there were varied legal systems that had been left behind by the previous occupying powers. As a result there were huge

prawno-instytucjonalnych ram konsultacji społecznych na poziomie samorzadu terytorialnego, [in:] P. Sobiesiak-Penszko (ed.), Prawo a partycypacja publiczna. Bilans monitoringu 2012, Instytut Spraw Publicznych, Warszawa 2013, pp. 24-45; J. Woźniczko, Konsultacje społeczne jako narzędzie partycypacji publicznej. Opracowania tematyczne, OT-666, Kancelaria Senatu, Warszawa 2019, pp. 3-24, http://www.senat.gov.pl/gfx/senat/pl/senatopracowania/171/plik/ ot_666/pdf, (20.12.2019); Z. Zychowicz, Konsultacje spoteczne w samorzadzie, Instytut Rozwoju Regionalnego, Szczecin 2014, pp. 9-228; Zasady dialogu spotecznego. Dokument programowy Rządu przyjęty przez Radę Ministrów w dniu 22 października 2002 r. Załacznik nr 1. Dialog społeczny - istota, pojęcia, metody, Rada Ministrów, Warszawa 2002, pp. 3-37; P. Uziębło, Demokracja partycypacyjna, Centrum Badań Społecznych, Gdańsk 2009, p. 231; M.M. Sienkiewicz, M. Sidor (eds.), Dialog obywatelski: formy, mechanizmy, bariery i perspektywy rozwoju, Wydawnictwo Fundacji Centrum Rozwoju Lokalnego, Lublin 2014, p. 242. 
differences in the legal regulations and practices as different districts reflected the influence of the particular partitioning power, and therefore the process of unifying required a lot of time. After the period of partitions, the Polish state formed its borders and built a parliamentary democracy. The reborn country underwent a very difficult and tough time concerning the organization of central and local administrative bodies, as the existing self-government ${ }^{4}$ system had also been inherited from the occupying countries ${ }^{5}$. The first plan of the Polish authorities was to speed up the unification process of the state at the political, legal, and administrative levels. Despite the fact that there was established tradition in the sphere of the local self-government, a few varied solutions were taken into consideration ${ }^{6}$.

The model that was applied by the political regime was the consequence of the clash of two opposing concepts. One of them was in favour of the development of a strongly centralized structure for administrative bodies. The other one called for the maximum degree of independence and autonomy for the local authorities ${ }^{7}$. The organization of the local self-government was advanced by the enacting of the Polish Constitution of the $17^{\text {th }}$ of March $1921^{8}$. The issue of self-government was introduced in some articles, which gave local self-government the rank of an essential characteristic of the state. The Constitution determined that the system of the Polish Republic was based on the principle of broad

4 For more about the roots and features of self-government, see, e.g., M. Stahl (ed.), Prawo administracyjne, pojęcia, instytucje, zasady $w$ teorii $i$ orzecznictwie, Wolters Kluwer, Warszawa 2013, p. 358.

5 See more in J. Sobczak, Idea samorzadowa w polskiej myśli politycznej XIX i początku XX wieku, [in:] B. Jastrzębski (ed.), Edukacja samorządowa, Wyższa Szkoła Pedagogiczna, Olsztyn 1997, pp. 40-41; E. Sokalska, The concepts of the local self-government in Poland in the first years of regaining independence, «Studia Prawnoustrojowe» 2015, vol. 28, pp. 305-320.

6 The discussion concening the nature of self-government in Poland was very vivid, see, e.g., J. Panejko, Geneza i podstawy samorządu europejskiego, Imprimerie, Paryż 1926, p. 130; T. Bigo, Związi publicznoprawne w świetle ustawodawstwa polskiego, Wyd. Kasy im. Mianowskiego, Warszawa 1928, p. 152; J. Staryszak, Prawo nadzoru nad administracja samorzadowa $w$ Polsce, Skład Główny w Instytucie im. J. Mianowskiego, Warszawa 1931, p. 24; A. Wereszczyński, Wiadomości o Polsce wspótczesnej. Ustrój i administracja państwa polskiego, Wydawnictwo Zakładu Narodowego imienia Ossolińskich, Lwów 1936, p. 232; M. Jaroszyński, Samorząd terytorialny $w$ Polsce. Stan obecny. Wnioski do reformy, Warszawa 1926, p. 1; J. Dobkowski, Uwagi Maurycego Zdzisława Jaroszyńskiego o ustroju Polski po śmierci marszałka Józefa Piłsudskiego, «Przegląd Sejmowy» 2019, vol. 3 (152), pp. 7-19.

7 B. Dolnicki, Samorząd terytorialny, Zakamycze 2001, p. 13.

8 Ustawa konstytucyjna Rzeczypospolitej Polskiej z dnia 17 marca 1921 r., Journal of Laws of the Republic of Poland 1921, no. 44, pos. 267. More about the constitution, see in A. Ajnenkiel, Konstytucje Polski w rozwoju dziejowym, Oficyna Wydawnicza Rytm, Warszawa 2001, pp. 156-180. 
self-government, which was combined with legislative powers, and therefore gave a certain degree of autonomy, especially in the field of public administration and culture. The Act introduced a fusion of two types of public administration and local self-government, with the detailed scope of their powers to be determined by additional bills 9 .

On the $23^{\text {rd }}$ of March 1933, a law was adopted that partially changed the local self-government system (ustawa o częściowej zmianie samorządu terytorialnego), it was also called the 'uniting act' ('ustawa scaleniowa') ${ }^{10}$, because it joined together the mosaic of the varied forms of self-government across Poland. Unfortunately, as the name suggests, the law was codified only in some parts, and the local government act only solved the most important issues. However, it was a very important step towards the unification of local self-government organization.

The Constitution of the $23^{\text {rd }}$ of April $1935^{11}$ brought some reduction in the laws concerning self-government in comparison with the previous constitution. It is significant that the geopolitical, political, and national situation of that time influenced such steps, with parts of selfgovernmental authorities, in fact, being reduced to advisory bodies of the central administration ${ }^{12}$. Nevertheless, local self-government became a significant aspect of social life, and it created conditions favorable to citizens engaging in the development of local structures.

9 Art. 3, 65 .

10 Ustawa z dnia 23 marca 1933 r. o częściowej zmianie ustroju samorządu terytorialnego, Journal of Laws of the Republic of Poland 1933, no 35, pos. 294. More about that act, see E. Sokalska, Organy samorzadowe miast niewydzielonych w świetle „ustawy scaleniowej” z 23 marca 1933 r., «Studia Prawnoustrojowe» 2004, vol. 3, pp. 151-160.

11 Journal of Laws of the Republic of Poland 1935, no. 30, pos. 227.

12 See the discussion concerning the reception of the constitutional provisions in the subject related literature, e.g., B. Dolnicki, Samorząd terytorialny..., pp. 51-52; M. Jaroszyński, Samorząd $w$ Konstytucji kwietniowej, «Samorząd» 1935, vol. 18, pp. 289-290; T. Bigo, Samorząd terytorialny w nowej konstytucji, [in:] Księga pamiątkowa ku czci Leona Pinińskiego, Lwów 1936, p. 11; M. Grzybowska, Samorząd miejski w II Rzeczypospolitej, «Samorząd Terytorialny» 2016, vol. 6, pp. 7-23; A. Tarnowska, Samorzadem, jak ongiś, Polska stać będzie. Zagadnienia genezy, podstawy prawnej, funkcjonowania i prób reformy samorządu wojewódzkiego w II RP, ze szczególnym uwzględnieniem Pomorza i Wielkopolski, «Studia z Dziejów Państwa i Prawa Polskiego» 2010, vol. 13 , pp. 183-209. 


\section{The post-war practices and the revival of the local self-government after political changes}

In Poland, the first years after World War II were a period when the 'new authorities' began to shape the new public administration. With the entry of the Red Army into Poland in 1944, a new administrative system was introduced. The new authorities introduced it in successive steps, as the opposition was liquidated, and their control over the entire society was strengthened. The newly created Polish state, which was not sovereign, as many of its policies were to dictated to it by the USSR and Kremlin, faced the difficult task of organizing the economic and political foundations of the state apparatus. The basic matters of the political nature of the state were settled relatively early, while the process organizing this under the aegis of the Polish Workers' Party (Polish: Polska Partia Robotnicza) of local authorities lasted until 1950. The lack of appropriate models for administration in the conditions of an emerging state, and the wish to avoid a simple imitation of the USSR in the first period in Poland, caused the need for the implementation of the old interwar model ${ }^{13}$. Despite the fact that the shape of local government after its reactivation in 1944 was assessed differently in the subject related literature, undeniably, the negative solutions included the elimination of an important feature of local government, i.e. the democratic elections of representative bodies by the society ${ }^{14}$.

As democracy disappeared and the centralization processes strengthened, the importance of collegial organs diminished, while the number of supervisory authorities increased. The intensification of this process took place in 1948-1950, and this led to the complete abolish of local selfgovernment. This was the result of the need to eliminate the opposition and strengthen the rulers, as any form of community self-organization could pose a threat to the totalitarian system of power.

13 See dekret Polskiego Komitetu Wyzwolenia Narodowego z 21 sierpnia 1944 r. o trybie powoływania władz administracji ogólnej I i II instancji, Journal of Laws 1944, no. 2, pos. 8, art. 1, 3-7, 9, and 11 . The following legal acts regulating local administration were: ustawa z 11 września 1944 r. o organizacji i zakresie działania rad narodowych (Journal of Laws 1946, no. 3, pos. 26 - update of the laws); dekret PKWN z 23 listopada 1944 r. o organizacji i zakresie działania samorządu terytorialnego (Journal of Laws 1944, no. 14, pos. 74).

14 See, e.g., B. Dolnicki, Organizacja i funkcjonowanie administracji terenowej, Uniwersytet Śląski, Katowice 1989, pp. 76-77; J. Służewski, Rady narodowe $i$ terenowe organy administracji państwowej, Wydawnictwo Prawnicze, Warszawa 1987, pp. 20-21; Z. Leoński, System organizacji i funkcjonowania terenowych organów przedstawicielskich i organów administracji państwowej PRL, PWN, Warszawa-Poznań 1989, p. 5. 
Thus the forms of local self-government that had been reactivated after World War II, were formally abolished by the legal act of the $20^{\text {th }}$ of March 1950 (ustawa z 20 marca 1950 r. o terenowych organach jednolitej władzy państwowej) ${ }^{15}$. The introduction of the 'uniform organs of state power', were associated with a new concept of the state, and it resulted in the introduction of a local administrative arrangements based directly on the Soviet model. Local government was considered a relic of the previous system, which was not suitable for the socialist state. Elected for three years National Councils became the new bodies of Polish government at the local level. Unfortunately, they were dependent on the decisions of the Polish United Workers Party (PZPR) and subordinated to higher-level National Councils, with little autonomy, provided the façade of democracy.

The public administration reforms of the 1990's reintroduced local self-government to the Polish state, where the gmina became the basic administrative unit ${ }^{16}$. In fact, this administrative unit is a reference back to a time in Polish history, when local self-government flourished in Polish social life. These decisions in the 1990's led to the formation of a dualistic model of public administration (governmental administration and self-governmental structures). Governmental structures were shaped according to centralism, but acted by means of a professional civil service, while self-governmental structures were led in a decentralized way by the local authorities appointed by the democratic elections.

It should be emphasized that the modern incarnation of self-government was first expressed in the constitutional act of the $17^{\text {th }}$ of October 199217. This was later developed in the Constitution of the Republic of Poland of the $2^{\text {nd }}$ of April 199718, which adopted the principle of the presumption of competence granted to self government in the matters of the performance of public tasks and assignments. The Act proclaimed that the most important principles of the political regime in the context of self-government (e.g., the territorial system of the Republic of Poland shall ensure the decentralization of public power ${ }^{19}$; the inhabitants of

15 Journal of Laws 1950, no. 14, pos. 130.

16 Ustwa z dnia 8 marca 1990 r. o samorządzie terytorialnym, Journal of Laws of the Republic of Poland 1990, no. 16, pos. 95; ustawa z dnia 22 marca 1990 r. o terenowych organach administracji ogólnej, Journal of Laws of the Republic of Poland 1990, no. 21, pos. 123.

17 Ustawa konstytucyjna z dnia 17 października 1992 r. o wzajemnych stosunkach między władzą ustawodawcza i wykonawczą Rzeczypospolitej Polskiej oraz o samorządzie terytorialnym, Journal of Laws of the Republic of Poland 1997, no. 16, pos. 94.

18 Journal of Laws of the Republic of Poland 1997, no. 78, pos. 483.

19 Art. 15. 
the basic units of territorial division form a self-governing community ${ }^{20}$; gmina is the basic unit of local government ${ }^{21}$; units of local government possess legal personality and performs public tasks in its own name ${ }^{22}$; local government perform public duties aimed at satisfying the need of a self-governing community ${ }^{23}$; gmina performs all tasks of local government, which are not reserved to the other units of the local government ${ }^{24}$; the self-governing nature of local government is protected by the $\operatorname{courts}^{25}$; self-government aims at satisfying the needs of the local community ${ }^{26}$; the units of local government may perform other public duties if there is the need of the state ${ }^{27}$; elections to the constitutive organs of the local government are direct, and executive organs are elected by the constitutive organs ${ }^{28}$; the units of the local self-government are assured their own revenues and public funds ${ }^{29}$; the internal organizational structure of the units is specified within their statutory limits ${ }^{30}$; the members of a self-government community may decide by means of referendum in some matters referring to their community ${ }^{31}$; the legality of the actions of local government is the subject of review ${ }^{32}$; the units of local government are free to associate $\left.{ }^{33}\right)$.

The purpose of the legislator was to grant local communities autonomy through the decentralization of public authorities, in order to create the conditions that would facilitate active resourceful local communities, and consequently, to develop some mechanism connected with the destructuring of the state economy. The change of a state economy was needed in order to meet international standards. To enhance community participation in the context of reaching political and economic decisions, thanks to the division of local and central authorities, was

\footnotetext{
20 Art. 16.

21 Art. 164.

22 Art. 165.

23 Art. 166, sec. 1.

24 Art. 164, sec. 3.

25 Art. 165, sec. 2.

26 Art. 165, sec. 1.

27 Art. 166, sec. 2.

28 Art. 169.

29 Art. 167.

30 Art. 169, sec. 4.

31 Art. 170.

32 Art. 171.

33 Art. 172.
} 
also an important aspect of these changes ${ }^{34}$. In the late 1990's, some further steps were undertaken in order to reform and modernize Polish public administration, and the effect was the introduction of two new levels of local self-government, namely the poviat administrative unit and the voivodship administrative unit. In order of size, the gmina was the smallest unit administrative, then came the poviat, and the voivodship became the largest adminstrative unit. There was a division of tasks performed by the governmental administration and self-governmental structures. Further changes in the structure and the principles of the activities of the Polish self-government at all the levels occurred after the enactment the law of the $11^{\text {th }}$ of April $2001^{35}$.

It should be emphasized that the legal activities in the sphere of the self-government mentioned above contributed to the development of Polish civil society in the $21^{\text {st }}$ century. Such institutions as elections to the local authorities, referendums ${ }^{36}$, and public consultations have become an essential part of the Polish political life. Information and communication technologies (ICT) have been developed in order to strengthen communication between self-governmental bodies and citizens ${ }^{37}$.

\section{The amendment of the $11^{\text {th }}$ of January 2018 to the Polish local self-government acts}

It is significant that local self-government should not be perceived as a purely static structure. The Polish legislator has worked on improving self-government by strengthening some participatory instruments ${ }^{38}$.

34 For more, see M. Bożek, Konstytucyjne podstawy partycypacji społecznej i formy jej realizacji w samorzadzie terytorialnym, «Przegląd Sejmowy» 2012, vol. 5 (112), pp. 100-102.

35 Ustawa z dnia 11 kwietnia $2001 \mathrm{r}$. o zmianie ustaw o samorządzie gminnym, o samorządzie powiatowym, o samorządzie województwa, o administracji rządowej w województwie oraz o zmianie niektórych ustaw, Journal of Laws of the Republic of Poland 2001, no. 45, pos. 497.

36 See more in M. Sidor, Referendum lokalne jako forma demokracji bezpośredniej, [in:] S. Michałowski, A. Pawłowska (eds.), Samorzad terytorialny w Polsce: społeczno-polityczne aspekty funkcjonowania, Wydawnictwo UMCS, Lublin 2004, pp. 186-194.

37 M. Kowalczyk, Cyfrowe państwo. Uwarunkowania i perspektywy, PWN, Warszawa 2019, pp. 260-262; K.A. Kuć-Czajkowska, J. Wasil, Elektroniczne oblicze władzy lokalnej w Polsce - dialog obywatelski przy użyciu narzędzi ICT, [in:] M.M. Sienkiewicz, M. Sidor (eds.), Dialog obywatelski: formy, mechanizmy, bariery i perspektywy rozwoju, Wydawnictwo Fundacji Centrum Rozwoju Lokalnego, Lublin 2014, pp. 111-122.

38 For more about the democratic innovations, see R. Markowski, Demokracja i demokratyczne innowacje. Z teoria $w$ praktyke, Instytut Obywatelski, Warszawa 2014, pp. 123-139, www:// http://www.instytutobywatelski.pl (10.12.2019). 
The consequence of such activities resulted in the amendment of the $11^{\text {th }}$ of January $2018^{39}$ to the Polish local self-government Acts, which was a further step towards reinforcing public participation at the local level. The amendment regulates some legal institutions, which can be perceived as the ones that strengthen the development of Polish civil society. They are: the civil budget, the citizens' legislative initiative, and the participation in the debate on the report on the condition of the local government unit.

The civil budget (also called the participatory budget) is perceived as a form of direct democracy. The civil budget enables the participation of the members of a local community in making some decisions about the allocation of a certain amount of public funds. The participatory budget grants the inhabitants of a given community (gmina, city district, poviat, and voividship) the possibility to decide on the allocation of public funds from the public budget for the implementation of public tasks falling within the scope of activities of this local self-governmental unit, recognized as significant by the inhabitants, which may be financed from public funds in a given budget year. Annually, the inhabitants in a direct voting designate a part of the budget expenditure. The tasks selected by residents within the framework of the civil budget should be included in the budget resolution of the local self-government unit. The draft budget resolution cannot significantly change or remove the tasks selected under the civil budget ${ }^{40}$. The institution of civil budget demands a special form of public consultations, which seems crucial in the context of the subjectivity of the members of local communities who are able to participate in the functioning of this institution of civil society ${ }^{41}$.

On the basis of the civil legislative initiative, members of local communities have the right to develop and submit a draft resolution, which, after meeting the formal conditions, should be submitted to vote at the meeting of the local self-government body. Despite the fact that the mentioned institution had been applied before, it became institutionalized according to the Amendment of 2018 mentioned above.

39 Ustawa z dnia 11 stycznia 2018 r. o zmianie niektórych ustaw w celu zwiększenia udziału obywateli w procesie wybierania, funkcjonowania i kontrolowania niektórych organów publicznych, Journal of Laws of the Republic of Poland 2018, pos. 130.

40 Art. 3, 5, and 10.

41 For more, see M. Augustyniak, R. Marchaj, Komentarz do art. 5 a ustawy o samorzadzie gminnym, [in:] B. Dolnicki (ed.), Ustawa o samorzadzie gminnym. Komentarz, Warszawa 2018, pp. 157-161. 
It is obligatory that a report on the state of the self-governmental unit is submitted by the executive organs every year. The law states that the inhabitants of a local self-governmental unit may participate in the debate on the report on the state should be also perceived as an expression of strengthening civil society at the local level. The legislation requires that the report on the state of the local government unit is presented will be debated in accordance with the statutory guidelines, which state that inhabitants can also take part in the debate.

\section{Conclusion}

In a model civil society citizens are treated as subjects in every sphere of political, economic, and cultural life. The operation of independent social institutions and organizations acting on the basis of pluralism should be supported by legislation. Solidarity, representativeness, co-responsibility, and mutual respect are necessary for the realization of local interests and needs. The political changes in Poland in the last two decades of the $20^{\text {th }}$ century laid the foundations for the development of the Polish democratic civil society. This process was associated with the decentralization of power and administration. Genuine local self-government was re-introduced thanks to the public administration reforms and the efforts of many people.

The perception of political decisions and their legitimization may be strengthened thanks to the appropriate identification and application of some participatory instruments. In Poland some legal institutions have been established and have been developed in order to bolster civil society in the sphere of local self-government. Elections to the local authorities, referendums, and public consultations are examples of these institutions. The latest amendment of the $11^{\text {th }}$ of January 2018 to the Polish local selfgovernment Acts is a further step towards the reinforcement of public participation at the local level. It introduced institutions such as the civil budget, participation in the debate on the report on the condition of the local government unit, and the civil legislative initiative, which might be enlisted in the context of the development of participatory institutions. These diverse forms of participation create genuine opportunities to shape the policies of local regions or districts. 


\section{Bibliography}

A. Arato, The Rise, Decline and Reconstruction of the Concept of Civil Society, and Directions for Future Research, [in:] A. Bibic, G. Graziano (eds.), Civil Society, Political Society, Democracy, Slovenian Political Association, Lubljana 1994.

M. Augustyniak, R. Marchaj, Komentarz do art. 5a ustawy o samorzadzie gminnym, [in:] B. Dolnicki (ed.), Ustawa o samorzadzie gminnym. Komentarz, Wolters Kluwer, Warszawa 2018.

T. Bigo, Związi publicznoprawne w świetle ustawodawstwa polskiego, Wyd. Kasy im. Mianowskiego, Warszawa 1928.

M. Bożek, Konstytucyjne podstawy partycypacji społecznej i formy jej realizacji $w$ samorzadzie terytorialnym, «Przegląd Sejmowy» 2012, vol. 5 (112).

J. Dobkowski, Uwagi Maurycego Zdzistawa Jaroszyńskiego o ustroju Polski po śmierci marszałka Józefa Pitsudskiego, «Przegląd Sejmowy» 2019, no. 3(152).

B. Dolnicki, Organizacja i funkcjonowanie administracji terenowej, Uniwersytet Śląski, Katowice 1989.

B. Dolnicki (ed.), Ustawa o samorzadzie gminnym. Komentarz, Wolters Kluwer, Warszawa 2018.

B. Dolnicki, Samorząd Terytorialny, Zakamycze 2001.

T.G. Grosse, Dialog społeczny i obywatelski w Unii Europejskiej, [in:] R. Towalski (ed.), Dialog społeczny. Najnowsze dyskusje i koncepcje, Centrum Partnerstwa Społecznego DIALOG, Fundacja Instytut Spraw Publicznych, Warszawa 2007.

M. Grzybowska, Samorząd miejski w II Rzeczypospolitej, «Samorząd Terytorialny» 2016, vol. 6 .

M. Jaroszyński, Samorząd w Konstytucji kwietniowej, «Samorząd» 1935, vol. 18.

M. Jaroszyński, Samorzqd terytorialny $w$ Polsce. Stan obecny. Wnioski do reformy, E. Wende i Ska, Warszawa 1924.

M. Kazimierczuk, Wolność zrzeszania sie jako element społeczeństwa obywatelskiego, «Studia Prawnoustrojowe» 2015, vol. 28.

M. Kowalczyk, Cyfrowe państwo. Uwarunkowania i perspektywy, PWN, Warszawa 2019.

K.A. Kuć-Czajkowska, J. Wasil, Elektroniczne oblicze władzy lokalnej w Polsce - dialog obywatelski przy użyciu narzędzi ICT, [in:] M.M. Sienkiewicz, M. Sidor (eds.), Dialog obywatelski: formy, mechanizmy, bariery i perspektywy rozwoju, Wydawnictwo Fundacji Centrum Rozwoju Lokalnego, Lublin 2014.

Z. Leoński, System organizacji i funkcjonowania terenowych organów przedstawicielskich i organów administracji państwowej PRL, PWN, Warszawa-Poznań 1989.

G. Makowski, Przeglad prawno-instytucjonalnych ram konsultacji spotecznych na poziomie samorzadu terytorialnego, [in:] P. Sobiesiak-Penszko (ed.), Prawo a partycypacja publiczna. Bilans monitoringu 2012, Instytut Spraw Publicznych, Warszawa 2013.

R. Markowski, Demokracja i demokratyczne innowacje. Z teoria w praktyke, Instytut Obywatelski Warszawa 2014, http://www.instytutobywatelski.pl (10.12.2019).

J. Panejko, Geneza i podstawy samorzadu europejskiego, Imprimerie, Paryż 1926.

M. Sidor, Referendum lokalne jako forma demokracji bezpośredniej, [in:] S. Michałowski, A. Pawłowska (eds.), Samorzad terytorialny $w$ Polsce: społeczno-polityczne aspekty funkcjonowania, Wydawnictwo UMCS, Lublin 2004.

M.M. Sienkiewicz, M. Sidor (eds.), Dialog obywatelski: formy, mechanizmy, bariery i perspektywy rozwoju, Wydawnictwo Fundacji Centrum Rozwoju Lokalnego, Lublin 2014. 
J. Służewski, Rady narodowe i terenowe organy administracji państwowej, Wydawnictwo prawnicze, Warszawa 1987.

J. Sobczak, Idea samorządowa $w$ polskiej myśli politycznej XIX i początku XX wieku, [in:] Edukacja samorządowa, B. Jastrzębski (ed.), Wyższa Szkoła Pedagogiczna w Olsztynie, Olsztyn 1997.

P. Sobiesiak-Penszko (ed.), Prawo a partycypacja publiczna. Bilans monitoringu 2012, Instytut Spraw Publicznych, Warszawa 2013.

E. Sokalska, Organy samorzq̨dowe miast niewydzielonych w świetle „ustawy scaleniowej” z 23 marca 1933 r., «Studia Prawnoustrojowe» 2004, vol. 3.

E. Sokalska, The concepts of the local self-government in Poland in the first years of regaining independence, «Studia Prawnoustrojowe» 2015, vol. 28.

M. Stahl (ed.), Prawo administracyjne, pojęcia, instytucje, zasady w teorii i orzecznictwie, Wolters Kluwer, Warszawa 2013.

J. Staryszak, Prawo nadzoru nad administracja samorzadowa w Polsce, Skład Główny w Instytucie im. J. Mianowskiego, Warszawa 1931.

A. Tarnowska, Samorzadem, jak ongiś, Polska stać będzie. Zagadnienia genezy, podstawy prawnej, funkcjonowania i prób reformy samorządu wojewódzkiego w II RP, ze szczególnym uwzglednieniem Pomorza $i$ Wielkopolski, «Studia z Dziejów Państwa i Prawa Polskiego» 2010, vol. 13.

R. Towalski (ed.), Dialog społeczny. Najnowsze dyskusje i koncepcje, Centrum Partnerstwa Społecznego DIALOG, Fundacja Instytut Spraw Publicznych, Warszawa 2007.

P. Uziębło, Demokracja partycypacyjna, Centrum Badań Społecznych, Gdańsk 2009.

A. Wereszczyński, Wiadomości o Polsce wspótczesnej. Ustrój i administracja państwa polskiego, Wydawnictwo Zakładu Narodowego imienia Ossolińskich, Lwów 1936.

J. Woźniczko, Konsultacje społeczne jako narzędzie partycypacji publicznej. Opracowania tematyczne, OT-666, Kancelaria Senatu, Warszawa 2019, http:// www.senat.gov.pl/gfx/senat/ $\mathrm{pl} /$ senatopracowania/171/plik/ot_666, pdf, (20.12.2019).

Z. Zychowicz, Konsultacje społeczne w samorzadzie, Instytut Rozwoju Regionalnego, Szczecin 2014 